\title{
$\begin{array}{r}\text { WAGENINGEN } \\ \text { UNIVERSITY \& RESEARCH } \\ \hline\end{array}$
}

\section{Certify sustainable retailers?}

\author{
Bush, S. R.
}

This is a "Post-Print" accepted manuscript, which has been published in "None"

This version is distributed under a non-commercial no derivatives Creative Commons (c) (1) $\Theta \Theta$ reproduction in any medium, provided the original work is properly cited and not used for commercial purposes. Further, the restriction applies that if you remix, transform, or build upon the material, you may not distribute the modified material.

Please cite this publication as follows:

Bush, S. R. (2017). Certify sustainable retailers? In J. Duncan, \& M. Bailey (Eds. ), Sustainable Food Futures: Multidisplinary solutions (pp. 133-144). (Routledge Studies in Food, Society and the Environment). Earthscan/Routledge. 


\title{
Certify sustainable retailers?
}

\author{
Simon R. Bush \\ Environmental Policy Group, Wageningen University, The Netherlands
}

\section{Introduction: limits to certification}

Aquaculture, the farming of fish and other aquatic organisms, has developed into one of the fastest growing sources of animal protein, and is important for international trade and domestic consumption alike (Belton \& Thilsted, 2014; Troell et al., 2014). In the context of food security, these farmed fish not only provide protein, but also make a fundamental contribution to securing a range of essential micronutrients (Thilsted et al., 2016).

Although increasingly varied in scale and intensity, for many of the species grown in tropical developing countries, aquaculture is still dependent in large part on small-holders, characterized by limited investment in assets, low operational costs, a large dependence on family labor, and a diversified portfolio of livelihood activities beyond fish farming (Edwards, 2013). As in other farming sectors, these small-holders are made economically vulnerable by their lack of investment capacity to expand production. But in addition, the vulnerability of small-holder aquaculture farmers is compounded by the high risk of shared poor water quality and the devastating effects of disease on their output.

Reducing the production risk across the industry is central to meeting wider ambitions of expanded global aquaculture production. One of the governance tools used to reduce risk is eco-certification, which sets voluntary auditable standards to improve ecological and social farming practices, and attach labels to products and enterprises that meet these standards (Hatanaka \& Busch, 2008). It is assumed that certified products enable farmers to benefit from reduced production costs, as well as increased market access and higher market prices (Bronnmann \& Asche, 2016; Wessells, 2002). The two most dominant aquaculture standards are the European-based Aquaculture Stewardship Council (ASC) standards and the US-based Global Aquaculture Alliance (GAA). While the number of certified farms has expanded at a phenomenal rate in recent years, this growth has been largely limited to larger-scale, vertically integrated firms (Jespersen et al., 2014; Trifković, 2014). Small-holders, who predominantly access Europe and the US on the basis of shortterm price contracts rather than long-term relational contracts, have proven less able to comply with these standards because of language, a lack of resources and poor literacy (Bush et al., 2013a). 
Although voluntary in principle, these standards have become commonly linked to export market access. Since 2010, retailers in the US and EU, two of the largest seafood import markets in the world by value (FAO, 2016), have pledged to only sell certified products in response to non-governmental organization (NGO) campaigns directed at the unsustainability of both capture fisheries and aquaculture (Sampson et al., 2015; Bush et al., 2013a). The timeline for these pledges has been gradually delayed from 2012 to 2018 as the challenges of realizing $100 \%$ provision of certified fish has become apparent. The consequence is that for producers to maintain access to these markets, they have to comply with these eco-standards. In the short term, these changes directly affect their livelihoods and incomes through increased costs and efforts, while any benefits from sustainability remain a long-term and uncertain proposition.

The question of who should be held responsible for sustainable production has been widely debated. But when it comes to the use of eco-standards, or any other legal or market requirement, the burden of demonstrating improvements towards sustainability is narrowly assigned to producers. Indeed, this assumption is the very basis of voluntary eco-certification; farmers should upgrade their production practices and farm infrastructure to demonstrate compliance with standards before being rewarded through the market (see Cashore, Auld \& Newsom, 2004, for a discussion on this key assumption). However, assuming farmers can simply respond to eco-standards as demanded by retailers does not take into consideration the highly differentiated capabilities of producers to respond. This is particularly important for aquaculture, which is ostensibly a developing-world activity, with over $85 \%$ of the volume of fish traded to Economic Co-operation and Development (OECD) countries stemming from developing countries (FAO, 2014). Shifting the burden of proof to producers in these developing countries does not consider the capacity of individual producers to demonstrate compliance with international standards, as well as the impact these standards have on them.

The assumption that producers have the capacity to respond to standards also overlooks key market dynamics, including how so-called 'lead firms' like retailers and food service companies coordinate global value chains and set contracts. Because of the strong levels of control that EU and US retailers and importers exercise in the seafood industry, they are more able to dictate the terms of trade to their suppliers. Not only do retailers demand sustainable seafood, they establish contracts in order to deliver high volumes with the lowest possible unit cost (Bjørndal et al., 2015; Fernández-Polanco \& Llorente, 2015). It remains unclear whether any market premiums are observed for those products certified, and there is even less clarity as to whether these premiums are passed up the chain to producers (Ha et al., 2012; Marschke \& Wilkings, 2014; Blomquist, Bartolino \& Waldo, 2015). What instead appears to be happening is that the cost of certification is pushed back up the chain to producers, placing a disproportionate burden on small- 
holders who are less able to absorb these costs. In classical Marxist terms, this can undermine the value of production and therefore the viability of the producers upon whom these retailers rely for their supply of seafood. If certification is going to make a meaningful contribution to sustainability, it appears new models are necessary - models that change the ways in which buyers like retailers can promote more inclusive and effective modes of improvement.

\section{Understanding value chain governance}

To further explore the potential of alternative modes of eco-certification in the aquaculture sector, we now turn to global value chain (GVC) governance. In general terms, GVC governance refers to how firms cooperate to coordinate and impose product specifications or 'qualities' on the production and trade of a product through to the point of consumption (Bair, 2009; Gereffi, 2014). As variously argued (Ponte \& Gibbon, 2005; Barrientos, Gereffi \& Rossi, 2011; Bush et al., 2015), such analysis exposes how firms and their suppliers take into consideration new norms, values and practices, including those related to sustainability. In doing so, GVC analysis enables us to then understand how lead firms seek greater stability and higher quality of the products they buy by setting clear product specifications over suppliers.

One way these retailers set product specifications for their suppliers is through voluntary eco-standards, which in the case of aquaculture are designed to translate new norms around sustainability. These standards are an example of what Gibbon, Bair and Ponte (2008) call 'governance as normalization,' or the 're-alignment' of practice throughout a chain to mirror or materialize an introduced standard, code or norm. In the agri-food sector, which includes aquaculture, these standards primarily target the farm and processor level, with the assumption that standard compliance at this level enables firms to generate assurance and credibility on the open global market (Hatanaka, Bain \& Busch, 2005). In turn, those complying with these standards are expected to benefit from balancing the risk and rewards of improved production practices, market access and even higher market prices.

Whether a lead firm chooses to employ voluntary eco-standards or not depends in large part on the level of control they (wish to) have over their suppliers. To understand this control or 'power' of some firms over others, Gereffi, Humphrey and Sturgeon (2005) developed the notion of governance as coordination, which explains the ways in which control is leveraged by the transmission of product specification (such as eco-standards) 
along the chain given the capacity of suppliers to meet these specifications. They identify a spectrum of five value-chain configurations, which move from low levels of so-called 'market' coordination, to high levels of so-called 'captive' coordination, and end in complete control over production through vertical integration (Gereffi, Humphrey \& Sturgeon, 2005). Moving along this spectrum, the degree of control and power over suppliers increases.

Governance as 'normalization', or setting and transferring norms to others in the value chain, can influence coordination in a number of ways. If more complex information can be incorporated in voluntary eco-standards, then retailers and food service companies may be able to maintain control over suppliers at a distance without having to directly invest in internal surveillance and control (Ponte, 2009). However, for sustainability standards, this creates a potential paradox. The sustainability norms embodied in these standards will force suppliers to develop new capabilities to improve the performance of production (Nadvi, 2014; Gereffi, Humphrey \& Sturgeon, 2005). But the high level of capabilities required will mean that retailers who aim to sell only certified products will likely exclude a large proportion of their suppliers from the market. In doing so, retailers may limit their own supply of product and limit any gains in sustainable production. Faced with this paradox, it appears a more inclusive certification model is needed.

\section{Rewarding 'developmental' chain coordination}

Developing a more inclusive improvement agenda for aquaculture certification requires a 'double shift'. First is a shift away from certification's focus on the farm scale and farmers as a target of regulation, to instead focus on the actors who play an active role in setting and demanding normative claims like sustainability. Second is a shift away from the lead firm as coordinator to the lead firm as partner for improvement. If both of these shifts can be realized, then more inclusive forms of sustainability improvements may be possible through eco-certification.

Moving beyond environmental or social standards at the farm level would then move to assessing the performance of buyers in supporting farmers to improve their production practices. This is a clear break from current observations that retailers use standards to outsource the cost and risk for dealing with complex normative issues like sustainability by pushing compliance and assessment back up value chains to their suppliers (Riisgaard et al., 2010). Making retailers the target of standards and certification would instead require them to internalize production risk, because their performance would be the subject of assessment. More specifically, they would be assessed on their support to suppliers to demonstrate improvements in production, whether that be a set of normative voluntary standards or basic legal compliance. In turn, these retailers would be rewarded by a certificate and/or eco-label for 'inclusive sustainability'. 
While such an approach would be a radical shift in how certification is applied in the aquaculture and wider seafood industry, the idea is not altogether new. In their study of Ikea, the lifestyle and furnishings multi-national corporation based in Sweden, Ivarsson and Alvstam (2010) observe what they refer to as the 'developmental' mode of chain coordination. They distinguish this form of coordination from other forms, such as armslength market relations with suppliers or 'capturing' suppliers through long-term binding contracts. They argue that the buying relationship Ikea has with their suppliers is developmental for two reasons. First, it is based on the provision of technological and organizational assistance, co-innovation, human capacity building, and financial and administrative advice, all aimed at helping suppliers meet their stringent product specifications. Second, Ikea does not capture these suppliers through exclusivity clauses in their contracts, but instead allows them to use the support they receive to expand their client base. The philosophy is that an open form of support increases the pre-competitive quality of their sector overall. What this means is that buyers work with producers, seeing them as a fundamental part of their business rather than simply suppliers of products.

Retailers are already partially engaging in developmental modes of coordination over currently 'un-certifiable' fish farmers through 'aquaculture improvement projects' (AIPs). Either coordinated directly by retailers or with the support of NGOs or consultants, AIPs support producers to move towards certification by, for example, directly financing improved farm practices, providing support for training on stocking, and pharmaceutical use, or paying for consultants to assist with the paperwork required to demonstrate improvement (SFP, 2016). In coordination terms, there are two general categories of these improvement projects (Tolentino-Zondervan et al., 2016). First, top-down projects promote improvement by linking market access and higher prices with standard compliance. Second, bottom-up projects develop a wide range of farmer and government capabilities with the hope that buyers will recognize and reward any improvements with market access. In both cases, it is hoped that these improvements will ultimately be supported with secure market access as buyers meet their demand for sustainable aquaculture production.

But unlike farm-level certification, which provides market recognition through an ecolabelled product, retailers engaging in these developmental-like forms of coordination receive very little recognition for the support they provide. This is because current certification schemes are based on the binary logic of compliance/non-compliance, which is in turn based on a static moment of auditing and certification. They do not, by design, take into consideration the capabilities of the producers being assessed, or the level of support that is given by other chain actors such as retailers. In other words, they are limited in making sustainability claims around their support because there remains contested interpretations of what makes a credible and effective aquaculture improvement project (Sampson et al., 2015). Retailers therefore run the risk of not being able to make 
claims in the market around the support they are providing because there is no independent third party substantiating their supposed support. It is exactly here that retail-level certification would fill this gap by providing a system of verification, market recognition, and ultimately greater incentives for further investment in small-holder support.

The impact of retail-level certification may also foster the kind of inclusive sustainability improvement that is currently lacking in the industry in two distinct ways. First, voluntary certification is most commonly taken up by producers who already exhibit a degree of compliance, or are willing and capable of applying (Tlusty, 2012). By inadvertently cherrypicking better performers, the degree of overall improvement across the industry remains limited. Recognizing and promoting continuous improvement towards sustainability would increase the involvement of less well-performing producers who cannot currently comply with high-level ASC or GAA standards. Such an inclusive approach is of key importance, because it is with these aquaculture producers that the greatest overall sustainability gains are still to be made. Making retailers responsible for demonstrating a developmental mode of sustainability support could also lead to considerable gains because the cost (and therefore the choice) to improve is no longer dispersed across literally millions of producers.

Second, shifting the cost of certification down the value chain would also put pressure on retailers and suppliers to search for innovative and more efficient forms of organizing aquaculture sustainability. One outcome would be the need for greater efficiencies for retailers to deliver support to individual producers beyond the farm through, for example, cooperative forms of management. Cooperative management of aquaculture has been met with mixed success, largely because of poor internal capacity, weak state support, and the complexity of environmental and health issues such as water quality and disease (Ha, Bush \& van Dijk, 2013). A developmental approach with buyer investment may prove more successful than current cooperative approaches because it would link the level and quality of producer support to the reputation and market demand of buyers. Because buyers would still be driven by environmental outcomes, the cooperatives they support may also engage in ecosystem or area-based forms of management (Macfadyen et al., 2016), and in doing so, link farm-level practices to issues like water quality that extend well beyond the boundaries of a single farm (Soto, Aguilar-Manjarrez \& Hishamunda, 2008).

The 'developmental' coordination of suppliers could also lead to improved risk management in the industry. By moving certification beyond the farm level and creating incentives for support from buyers in export markets, opportunities for insurance and new forms of financing may also emerge. Such opportunities would be transformative in the seafood sector in developing countries, given the high degree of production risk experienced by producers and the associated lack of formal insurance and finance 
opportunities (WorldFish, 2011). The outcome would be two-fold: producers would benefit from receiving the necessary capacity to reduce production risk and sustainably intensify production, while buyers would benefit from a more stable supply of sustainably produced fish.

\section{New or existing certification schemes?}

Would such a system need new certification schemes beyond the ASC and GAA? Not necessarily. The goal of these certification schemes is to assure buyers that the products they are purchasing have been responsibly produced. While this goal would remain the same, a new standard would be required that focuses on verifying the developmental credentials of buyers. To this end, both ASC and GAA could incorporate a new 'developmental' or 'inclusive improvement' standard to their certification. GAA already offers a reporting-based Best Aquaculture Practices (BAP) standard that is modular to the extent that different 'sub-standards' are applied across four processes in the chain processing plants, farms, feed mills and hatcheries - with the certification of each process (in the order presented here) rewarded with an additional star rating (GAA, n.d.). Moving to a retail-level certification may result in the addition of a standard 'star'. ASC, on the other hand, is a metric-based farm-level standard. For them, it may be that a new standard, auditing approach and label would be required. If neither ASC nor GAA would be interested in adapting the scope of their existing certification, a standard or accreditation could be developed.

The scope of a developmental standard could reflect the need to support the capabilities of producers or communities of producers to continually improve their production rather than setting a single and 'fictitious' level or goal of sustainability (Micheli et al., 2014; Tlusty \& Thorsen, 2016). In practical terms, such a standard could follow Ivarsson and Alvstam (2010) and focus on new process-oriented categories, such as the provision of technological and organizational assistance, co-innovation, human capacity building, and/or financial and administrative advice. Alternatively, the standard could focus on supporting the broader capabilities of producer communities by investing in social and human capital. Doing so, they argue, would require assessing support for education, socioeconomic development, fair conditions of employment and diversification of livelihoods in cases of overexploitation. Bringing in these wider categories for an industry like aquaculture may appear to be moving beyond the scope responsibility of any buyer, but it is not without precedent. As notions of 'extended responsibility' of the retail sector grows (Bush et al., 2015), especially in the context of sourcing from developing countries, such activities may become the norm, especially if EU and US firms see such activities as a means to an end: that of securing a 'sustainable' product. 
Finally, the emergence of a developmental standard would not make farm-level standards irrelevant. Aquaculture sub-sectors that are able to absorb and cope with the requirements of certification could still opt for one of the existing global standards. But for producers unable to cope, engaging with retailers that offer developmental support could be a means to create long-term market relations and/or develop their capabilities to engage directly with the existing global standards. By providing alternatives, such producers will, at the very least, have more and different incentives for improvement than is currently the case.

\section{Concluding remarks}

A retail-led 'developmental' model for aquaculture sustainability would inevitably create new kinds of dependencies between buyers and producers. And there is no guarantee that buyer certification will improve conditions for developing-world producers to be incorporated into global seafood value chains. But by giving market recognition for 'developmental' modes of chain coordination, we can ensure that the responsibility for sustainable aquaculture is not placed on those with the least capacity for independent improvement. Instead of retailers undermining the capacity of farmers to respond to sustainability demands, responsibility will be placed at the feet of retailers (and other buyers) who do not replace the end consumer but do orchestrate global demand for fish products. Such an approach would also reinvigorate market-based approaches to sustainability governance. If retailers and other buyers are being recognized for the support they provide rather than the individual products on their shelves, then the race to be the greenest grocer on the high street may yet still drive substantial sustainability improvements in aquaculture and other sectors. 


\section{Recipe: Canh chua cá tra (sweet and sour pangasius fish soup)}

Ingredients

7 cups water

3 tablespoons tamarind paste

2 tablespoons (preferably palm) sugar

2 large tomatoes, sliced and diced

1 celery stick, chopped into bite-size pieces

1 tablespoon (Vietnamese) fish sauce (Nước mắm)

$300 \mathrm{~g}$ Vietnamese pangasius (cá tra, a kind of catfish) cutlets (not fillets!), which you'll have to search for at a Vietnamese or Asian specialty supermarket

$100 \mathrm{~g}$ Asian bean sprouts

1 teaspoon finely chopped red chilli, sweet basil and fresh coriander

Preparation

Put the tamarind paste in cold water to dilute and strain.

Throw the tamarind paste into a pot with the water and add the sugar, tomatoes, celery and fish sauce. Let simmer for about 15 minutes.

Add the pangasius cutlets, bean sprouts and chillies, and simmer for a further 3 minutes.

Serve in individual soup bowls and garnish with plenty of mint, sweet basil or coriander.

Serve with a side dish of Vietnamese fish sauce.

(Adapted from www.food.com)

\section{Critical questions}

1. Why would (or wouldn't) a retailer agree to be certified against a developmental standard? 
2. Does a developmental standard overcome the constraints that developing-world or small-holder producers face when selling to export markets?

3. What might the impact of a development standard be for local and global food security?

4. Are market-based governance approaches, like voluntary eco-certification, the only way to promote inclusive modes of sustainability improvement? Can you think of others?

\section{Acknowledgements}

This chapter contributes to research under the Netherlands Organisation for Scientific Research (NWO) funded 'Supermarket Supported Area-based Management and Certification of Aquaculture in Southeast Asia' (SUPERSEAS) project (grant number W08.250.205).

\section{References}

Bair, J. (2009) Global commodity chains: Genealogy and review. In: Bair, J. (ed.) Frontiers of Commodity Chain Research. Stanford, Stanford University Press, pp. 1-34.

Barrientos, S., Gereffi, G. \& Rossi, A. (2011) Economic and social upgrading in global production networks: A new paradigm for a changing world. International Labour Review. 150 (3-4), 319-340. Available from: doi:10.1111/j.1564-913X.2011.00119.x [Accessed: 1st March 2017].

Belton, B. \& Thilsted, S. H. (2014) Fisheries in transition: Food and nutrition security implications for the global South. Global Food Security. 3 (1), 59-66.

Bjørndal, T., Child, A., Lem, A. \& Dey, M. M. (2015) Value chain dynamics and the smallscale sector: A summary of findings and policy recommendations for fisheries and aquaculture trade. Aquaculture Economics \& Management. 19 (1), 148-173. Available from: doi:10.1080/13657305.2015.994241 [Accessed: 1st March 2017].

Blomquist, J., Bartolino, V. \& Waldo, S. (2015) Price premiums for providing eco-labelled seafood : Evidence from MSC-certified cod in Sweden. Journal of Agricultural Economics. 66 (3), 690-704. Available from: doi:10.1111/1477-9552.12106 [Accessed: 1st March 2017].

Bondad-Reantaso, M. G. \& Subasinghe, R. P. (eds.) (2013) Enhancing the contribution of small-scale aquaculture to food security, poverty alleviation and socio-economic 
development. FAO Fisheries and Aquaculture Proceedings 31, 21-24th April 2010, Hanoi, Viet Nam. Rome, Food and Agriculture Organization of the United Nations.

Bronnmann, J. \& Asche, F. (2016) The value of product attributes, brands and private labels: An analysis of frozen seafood in Germany. Journal of Agricultural Economics. 67 (1), 231-244. Available from: doi:10.1111/1477-9552.12138 [Accessed: 1st March 2017].

Bush, S. R., Belton, B., Hall, D., Vandergeest, P., Murray, F. J., Ponte, S., Oosterveer, P., Islam, M. S., Mol, A. P. J., Hatanaka, M., Kruijssen, F., Ha., T. T. T., Little, D. C. \& Kusumawati, R. (2013a) Certify sustainable aquaculture? Science. 341 (6150), 10671068. Available from: doi:10.1126/science.1237314 [Accessed: 1st March 2017].

Bush, S. R., Oosterveer, P., Bailey, M. \& Mol., A. P. J. (2015) Sustainability governance of chains and networks: A review and future outlook. Journal of Cleaner Production. 107, 8-19. Available from: doi:10.1016/j.jclepro.2014.10.019 [Accessed: 1st March 2017].

Bush, S. R., Toonen, H., Oosterveer, P. \& Mol, A. P. J. (2013b) The 'devils triangle' of MSC certification: Balancing credibility, accessibility and continuous improvement."Marine Policy. 37 (1), 288-293. Available from: doi: 10.1016/j.marpol.2012.05.011 [Accessed: 1st March 2017].

Cashore, B., Auld, G. \& Newsom, D. (2004) Governing Through Markets: Forest Certification and the Emergence of Non-State Authority. New Haven and London, Yale University Press.

Edwards, P. (2013) Review of small-scale aquaculture: Definitions, characterization, numbers. In Bondad-Reantaso, M. G. \& Subasinghe, R. P. (eds.) Enhancing the Contribution of Small-Scale Aquaculture to Food Security, Poverty Alleviation and Socio-Economic Development: FAO Fisheries and Aquaculture Proceedings 31, 21-24th April 2010, Hanoi, Viet Nam. Rome, Food and Agriculture Organization of the United Nations, pp. 37-61.

FAO. (2014) The State of World Fisheries and Aquaculture: Opportunities and Challenges. Rome, Food and Agriculture Organization of the United Nations.

FAO. (2016) The State of the Worlds Fisheries and Aquaculture: Contributing to Food Security and Nutrition for All. Rome, Food and Agriculture Organization of the United Nations.

Fernández-Polanco, J. \& Llorente, I. (2015) Price transmission in the Spanish fresh wild fish market. Aquaculture Economics \& Management. 19 (1), 104-124. Available from: doi:10.1080/13657305.2015.994238 [Accessed: 1st March 2017]. 
Gereffi, G. (2014) Global value chains in a post-Washington consensus world. Review of International Political Economy. 21 (1), 9-37. Available from: doi:10.1080/09692290.2012.756414 [Accessed: 1st March 2017].

Gereffi, G., Humphrey, J. \& Sturgeon, T. (2005) The governance of global value chains: An analytic framework. Review of International Political Economy. 12 (1), 78-104. Available from: doi:10.1080/09692290500049805 [Accessed: 1st March 2017].

Gibbon, P., Bair, J. \& Ponte, S. (2008) Governing global value chains: An introduction. Economy and Society. 37 (3), 315-338. Available from: doi:10.1080/03085140802172656 [Accessed: 1st March 2017].

Global Aquaculture Alliance (GAA). (n. d.) Multi-star integrity. Available from: http://bap.gaalliance.org/program-integrity/multi-star-integrity/ [Accessed: 1st March 2017].

Ha, T. T. T., Bush, S. R, Mol, A. P. J. \& van Dijk, H. (2012) Organic coasts? Regulatory challenges of certifying integrated shrimp - mangrove production systems in Vietnam. Journal of Rural Studies. 28 (4), 631-639. Available from: doi: 10.1016/j.jrurstud.2012.07.001 [Accessed: 1st March 2017].

Ha, T. T. T., Bush, S. R. \& van Dijk, H. (2013) The cluster panacea? Questioning the role of cooperative shrimp aquaculture in Vietnam. Aquaculture. 388-391, 89-98.

Hatanaka, M., Bain, C. \& Busch, L. (2005) Third-party certification in the global agrifood system. Food Policy. 30 (3), 354-369. Available from: doi: 10.1016/j.foodpol.2005.05.006 [Accessed: 1st March 2017].

Hatanaka, M. \& Busch, L. (2008) Third-party certification in the global agrifood system: An objective or socially mediated governance mechanism? Sociologia Ruralis. 48 (1), 73-91.

Ivarsson, I. \& Alvstam, C. G. (2010) Supplier upgrading in the home-furnishing value chain: An empirical study of IKEA's sourcing in China and South East Asia. World Development. 38 (11), 1575-1587. Available from: doi: 10.1016/j.worlddev.2010.04.007 [Accessed: 1st March 2017].

Jespersen, K. S., Kelling, I., Ponte, S. \& Kruijssen, F. (2014) What shapes food value chains? Lessons from aquaculture in Asia. Food Policy. 49 (1), 228-240. Available from: doi: 10.1016/j.foodpol.2014.08.004 [Accessed 1st March 2017].

Macfadyen, S., Tylianakis, J. M., Letourneau, D. K., Benton, T. G., Tittonell, P., Perring, M. P., Gómez-creutzberg, C., Báldi, A., Holland, J. M., Broadhurst, L., Okabe, K., Renwick, A. R., Gemmill-Herren, B. \& Smith, H. G. (2016) The role of food 
retailers in improving resilience in global food supply. Global Food Security. 7, 1-8. Available from: doi: 10.1016/j.gfs.2016.01.001 [Accessed: 1st March 2017].

Marschke, M. \& Wilkings, A. (2014) Is certification a viable option for small producer fish farmers in the global south? Insights from Vietnam. Marine Policy. 50 (A), 197-206. Available from: doi: 10.1016/j.marpol.2014.06.010 [Accessed: 1st March 2017].

Micheli, F., De Leo, D., Shester, G. G., Martone, R. G., Lluch-Cota, S. E., Butner, C., Crowder, L. B., Fujita, R., Gelcich, S., Jain, M., Lester, S. E., McCay, Pelc, R. \& Sáenz-Arroyo, A. (2014) A system-wide approach to supporting improvements in seafood production practices and outcomes. Frontiers in Ecology and the Environment. 12 (5), 297-305. Available from: doi:10.1890/110257 [Accessed: 1st March 2017].

Nadvi, K. 2014. "Rising powers" and labour and environmental standards. Oxford Development Studies. 42 (2), 137-150. Available from: doi: 10.1080/13600818.2014.909400 [Accessed: 1st March 2017].

Ponte, S. (2009) Governing through quality: Conventions and supply relations in the value chain for South African Wine. Sociologia Ruralis. 49 (3), 236-257. Available from: doi: 10.1111/j.1467-9523.2009.00484.x [Accessed 1st March 2017].

Ponte, S. \& Gibbon, P. (2005) Quality standards, conventions and the governance of global value chains. Economy and Society. 34 (1), 1-31. Available from: doi: 10.1080/0308514042000329315 [Accessed: 1st March 2017].

Riisgaard, L., Bolwig, S., Ponte, S., Du Toit, A., Halberg, N. \& Matose, F. (2010) Integrating poverty and environmental concerns into value-chain analysis: A strategic framework and practical guide. Development Policy Review. 28 (2), 195216.

Sampson, G. S., Sanchirico, J. N., Roheim, C. A., Bush, S. R., Taylor, J. E., Allison, E. H., Anderson, J. L., Ban, N. C., Fujita, R., Jupiter, S. \& Wilson, J. R. (2015) Secure sustainable seafood from developing countries. Science. 348 (6234), 504-506.

SFP. (2016) Ca Mau Shrimp aquaculture improvement project. Available from: www.sustainablefish.org/aquaculture-improvement/ca-mau-shrimp-aip (Login required).

Soto, D., Aguilar-Manjarrez, J. \& Hishamunda, N. (eds.) (2008) Building an Ecosystem Approach to Aquaculture. FAO Fisheries and Aquaculture Proceedings, 7-11th May, 2007, Palma de Mallorca, Spain. Rome, Food and Agriculture Organization of the United Nations. 
Thilsted, S. H., Thorne-lyman, A., Webb, P., Rose Bogard, J., Subasinghe, R., Phillips, M. J. \& Allison, E. H. (2016) Sustaining healthy diets: The role of capture fisheries and aquaculture for improving nutrition in the post-2015 era. Food Policy. 61, 126-131. Available from: doi:10.1016/j.foodpol.2016.02.005 [Accessed: 1st March 2017].

Tlusty, M. F. (2012) Environmental improvement of seafood through certification and ecolabelling: Theory and analysis. Fish and Fisheries. 13 (1), 1-13. Available from: doi: 10.1111/j.1467-2979.2011.00404.x [Accessed: 1st March 2017].

Tlusty, M. F. \& Thorsen, Ø. (2016) Claiming seafood is 'sustainable' risks limiting improvements. Fish and Fisheries. July. Available from: doi: 10.1111/faf.12170 [Accessed: 1st March 2017].

Tolentino-Zondervan, F., Berentsen, P., Bush, S. R., Digal, L. \& Lansink, A. O. (2016) Fisher-level decision making to participate in Fisheries Improvement Projects (FIPs) for yellowfin tuna in the philippines. PloS One. 11 (10), 1-22. Available from: doi: 10.1371/journal.pone.0163537 [Accessed: 1st March 2017].

Trifković, N. (2014) Certified standards and vertical coordination in aquaculture: The case of pangasius from Vietnam. Aquaculture. 433, 235-246. Available from: doi: 10.1016/j.aquaculture.2014.06.010 [Accessed: 1st March 2017].

Troell, M., Naylor, R. L., Metian, M., Beveridge, M., Tyedmers, P. H., Folke, C., Arrow, K. J., Barrett, S., Crépin, A., Ehrlich, P. R., Gren, A., Kautsky, N., Levin, S. A., Nyborg, K., Österblom, H., Polasky, S., Scheffer, M., Walker, B. H., Xepapadeas, T. \& de Zeeuw, A. (2014) Does aquaculture add resilience to the global food system? PNAS. 111 (37), 13257-13263. Available from: doi: 10.1073/pnas.1404067111 [Accessed: 1st March 2017].

Valder Valderrama, D., N. Hishamunda \& X. Zhou (2010) Estimating employment in world Aquaculture. FAO Fisheries and Aquaculture Newsletter 45 24-25.

Wessells, C. R. (2002) The economics of information: Markets for seafood attributes. Marine Resource Economics. 17 (2), 153-162.

WorldFish. (2011) Financing smallholder aquaculture enterprises. WorldFish. Policy Brief 2011-07. 